\title{
Enzyme Unit
}

National Cancer Institute

\section{Source}

National Cancer Institute. Enzyme Unit. NCI Thesaurus. Code C64778.

A unit of catalytic activity measurement defined as the quantity of a particular enzyme that catalyzes the transformation of one micromole of the substrate per minute under standard conditions for specified assay system. The usage of this unit is discouraged in favor of the katal by International Federation of Clinical Chemistry and Laboratory Medicine due to lack of its coherence with the SI system. One enzyme unit is equal to 16.667 nanokatals. 